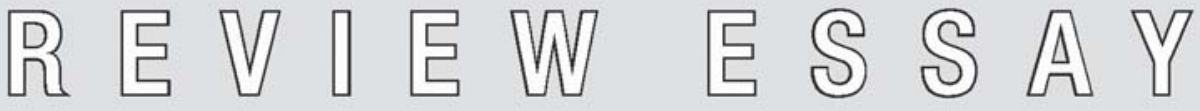 af Signe Kjær J ørgensen
}

\section{Religion \\ - det 21. århundredes udfordring}

I reviewet vurderes 3 aktuelle antologier fra Københavns Universitets satsningsområde "Religion i det 21. århunderede". Antologibidragene indplaceres i en bredere kirkehistorisk sammenhæng, og deres konklusioner diskuteres og perspektiveres.

I det 20. århundrede begyndte religion så småt at gå af mode som forskningsfelt. Efter 2. Verdenskrig blev den danske befolkning mere sekulariseret, og religionens samfundsmæssige betydning blev derfor betragtet som minimal. Så pludselig d. 11. september 2001 blev religionen igen genstand for opmærksomhed, fordi det var religiøse fundamentalister, der stod bag angrebet på World Trade Center. Terrorangrebet d. 11. september satte fokus på de mange religiøse bevægelser som reagerede mod den dominerende globalisering, amerikanisering og sekularisering. Taarbæk-præsten Thorkild Grosbøll, reagerede også som en del af en endog meget lille del dansk bevægelse mod det, han betragtede som den dominerende forståelse af forholdet til Gud blandt præster i Folkekirken, da han d. 23. maj 2003 udtalte, at han ikke troede på Gud.

Selvom Thorkild Grosbølls udtalelser ikke fik verdensomspændende betydning, så fik de dog danskerne til på ny at forholde sig til det klassiske spørgsmål om, hvorvidt Gud bør anskues som immanent eller transcendental. Spørgsmålet om hvorvidt Gud bør opfattes som en del af mennesket eller som en egenartet skikkelse, har i en dansk kontekst ofte været rejst siden N.F.S. Grundtvig skrev sine berømte prædikener i 1800-tallet. Grundtvig gjorde sig 
til talsmand for en immanent gudsopfattelse, hvor Gud blev betragtet som manifesteret i det enkelte menneske. Modsat denne opfattelse, plæderede eksistensfilosoffen Søren Kierkegaard i samme periode for, at Gud var kvalitativt forskelligt fra mennesket. Når spørgsmålet om Guds forhold til det enkelte menneske på ny dukkede op i 2003, var det blandt foranlediget af den tiltagende multireligiøsitet i det danske samfund, og det er i denne kontekst, at de tre samfundsvidenskabelige antologier fra Københavns Universitets satsningsområde "Religion i det 21. århundrede" skal læses.

De tre antologier er Gudstro i Danmark (2005), Gudebilleder-Ytringsfrihed og religion i en globaliseret verden (2006) og Vendepunkter -Religion mellem konflikt og forsoning (2007). De tre antologier komplementerer hinanden, i det de alle handler om religion i det 21. århundrede. Perspektivet er dog forskelligt. Forfatterne i Gudstro i Danmark behandler, som titlen også antyder, danskernes forståelse af Gud, mens forfatterne i de to senere antologier tillige anlægger et internationalt perspektiv. Der forekommer en vis fremadskridende erkendelse hos enkelte forfattere, og derfor anmeldes antologierne i den publicerede rækkefølge. Det skal bemærkes, at alle antologierne er tværfaglige, og at de derfor indeholder meget forskellige bidrag. Den røde tråd i de bidrag som ekspliciteres i dette review er, at de i deres sammenhæng giver et socialvidenskabeligt indblik i hhv. danskernes gudstro, problemstillingerne i forbindelse med Muhammed-krisen i 2006 og den filosofiske forståelse af bevægelsen fra konflikt til forsoning.

Peter Lüchau leverer som den første i Gudstro i Danmark et overbevisende argument for, at sekulariseringen af samfundets institutioner ikke har medført en aftagende individuel tro. Modsat de tendenser, man har observeret i 1970'erne og 1980'erne, så er der 1990'erne klart en stigning i antallet af troende mennesker. Det er dog det, som Lüchau betegner som en individualiseret tro, og spørgsmålet der melder sig, og som i øvrigt besvares senere i antologien er, om den nye individualiserede gudsdyrkelse kan og bør rummes inden for folkekirken. Hans Raun Iversen viser følgende, hvordan syv idealtyper for religion, som findes i en dansk kontekst, deler strukturen: Gud, moral, bestemmelse, og hvordan denne tredeling muliggør en frugtbar vekselvirkning mellem forskellige danske trossamfund. Raun Iversen argumenterer endvidere for, at danskernes religionsudøvelse sker på et folkekirkeligt grundlag, og at dette udgør det, han billedligt betegner som danskernes "religionspark". Margit Warburg viderefører i et vist omfang denne argumentation, idet hun viser, hvordan normerne i samfundet - den såkaldte civilreligion- bliver medieret igennem en lang række forskellige samfundsmæssige institutioner. Hendes pointe er, at denne mediering ikke kun sker gennem Folkekirken. Denne forståelse deler Stig Hjarvard, som argumenterer for, at folkekirkens funktion både erstattes af og medieres igennem den TV- transmitterede underholdningsindustri. Julegudstjenester og høstgudstjenester, som tidligere samlede danskerne årligt, erstattes nu med sofahygge om TV-serier som Matador eller 
Riget, mens de rester fra folkekirken som bevares, bliver det via transmissioner fra royale bryllupper og barnedåber. Selv om der stadig findes en stærk tilknytning til folkekirken blandt danskerne, så findes der også religiøse rebeller, som protesterer mod den relativt fastlåste folkekirkelige liturgi. Olav Hammer analyserer i sit antologibidrag hjemmesiden selvet.dk og viser, hvordan mange danskere organiserer sig i ny-åndelige communities på internettet. Spørgsmålet om folkekirkens rummelighed, som er blevet aktualiseret i flere antologibidrag, tages op af Cecilie Rubow. Hun har interviewet en række præster om deres forhold til Gud, og gennem læsningen af hendes analyse viser det sig, at Thorkild Grosbølls forhold til Gud langt fra er enestående.

I antologien Gudebilleder, der - med direkte henvisning til Muhammedkrisen - har undertitlen Ytringsfrihed og religion i en globaliseret verden, behandles spørgsmålet om ytringsfrihed i forhold til religiøse hensyn. Margit Warburg viser, hvordan globaliseringen har påvirket spillereglerne for forholdet mellem religion og (national?)stat. Hun analyserer, hvordan fire specifikke karakteristika ved globaliseringen fik betydning for, at Muhammed-krisen eskalerede. Jørgen $\mathrm{S}$. Nielsen argumenterer for, at religion indtager en mindre betydningsfuld rolle i de forholdsvis sekulære europæiske samfund, og at Muhammedkrisen opstod, fordi vi i Danmark har svært ved at forstå, at religion har stor betydning i muslimske samfund. Han giver endvidere et indblik i nyere retninger inden for Islam. I forhold til Jørgen S. Nielsens historiske perspektiv anlægger Ole Wæver en politologisk synsvinkel. Ole Wæver opfatter Muhammed-krisen som et eksempel på en ny type konflikter, som skabes, fordi globaliseringen har udraderet skellet mellem indenrigs- og udenrigspolitik. Ole Wæver argumenterer for, at individet pålægges det diplomatiske ansvar, som tidligere har hvilet på staterne, og at Muhammed-krisen opstod, fordi enkeltpersoner (her Carsten Juste og Flemming Rose) ikke var bevidste om deres diplomatiske ansvar. En anden pointe, som Ole Wæver fremhæver er, at diplomatisk ansvar er forbundet med bevidstheden om, at alt hvad der er lovligt ikke nødvendigvis er ansvarligt. Det var legalt, at publicere de 12 karikaturer, men kulturel tolerance burde have afholdt Jyllandspostens redaktion fra at trykke karikaturtegningerne. Med henvisning til det multikulturelle U.S.A. argumenterer Ole Wæver for, at kulturel hensynstagenhed kan forebygge situationer, som Muhammed-krisen, og at man dermed kan undgå at indføre censur i form af (endnu) en legal indskrænkning af ytringsfriheden. Spørgsmålet er dog, om kulturel hensyntagenhed kan erstatte legale indskrænkninger af ytringsfriheden? Som læser foranlediges man til at spørge, om ikke den amerikanske "kultur af hensyntagenhed" kan tænkes at være et produkt af mange års retspraksis? Det amerikanske samfund er jo om noget et samfund, hvor det moderne subjekts ukrænkelighed har resulteret i en stigende legal indskrænkning af ytringsfriheden, sådan som det også er set internationalt med FN's såkaldte racismekonvention (1965) og kvindekonvention (1979), som også Danmark har ratificeret. Stig Hjarvard anskuer ligesom Ole 
Wæver Muhammed-krisen som en konsekvens af globaliseringen, men vel at mærke mediernes globalisering. I hans optik skyldtes krisen, at de 12 karikaturtegninger blev rekontekstualiseret af de globale medier, sådan at tegningerne i forskellige nationale offentligheder blev tillagt et nyt - ofte politiseret - indhold. Karikaturtegningernes fremkomst tolker han på sin side som et led i en repolitisering af den danske presse, som har fundet sted op gennem 1990'erne. Teologen Niels Henrik Gregersen analyserer i sit antologibidrag forholdet mellem religionsfrihed og retsstaten. Overordnet ser han en tendens til en sekularisering på samfundsniveau, og derfor vurderer han, at religiøst funderede konflikter bedst forebygges ved en erkendelse af, at alle religioner har deres sårbarheder, og at det er den enkeltes ansvar at vise hensyn. Niels Henrik Gregersens analyse komplementerer Lüchaus analyse fra 2005, idet Gregersen argumenterer for, at de velinstitutionaliserede trossamfund mister betydning i det offentlige rum, mens Lüchau argumenterer for at individualiserede, pragmatiske trosformer vinder øget indpas. Hans Raun Iversen går i dybden med begrebet anerkendelse, som han anser for centralt i den aktuelle samfundsdebat. Begrebet anerkendelse skaber en vis dynamik i den socio-kulturelle kontekst - religionsparken - som Raun Iversen jf. hans tidligere antologibidrag fra 2005 anskuer som grundlag for religionsudøvelse i Danmark. Anerkendelsesbegrebets centralitet kendes blandt andet fra Axel Honneths socialvidenskabelige skrifter - mest kendt Kampen for anerkendelse og viser indirekte hvilket normer Gudebilleder er skrevet på grundlag af. Efter læsning af antologien efterlades man med den klare overbevisning, at afvejningen mellem demokratiske frihedsrettigheder i forhold til minoritetstro altid bør være funderet i phronesis - den praktiske visdom - i den konkrete sociale og kulturelle kontekst. I forhold til antologiens formål, om at skabe øget forståelse af forholdet mellem ytringsfrihed og religiøs doxa i en globaliseret verden, kunne der være ønsket et bidrag, hvor der blev taget udgangspunkt i et euro-islamisk perspektiv. Hvordan opfattede herboende kulturelle muslimer sagen om Jyllandspostens Muhammed-karikaturer, og hvordan synes de generelt at hensynet til ytringsfriheden bør afvejes i forhold til minoritetshensyn i Danmark? Ligeledes kunne der være fremført et argument fra et mere ortodoks muslimsk perspektiv.

I antologien Vendepunkter - Religion mellem konflikt og forsoning behandles spørgsmålet om religiøs konfliktløsning og soning. Det altovervejende normative grundlag for antologibidragene er, at der bør skabes forsoning mellem forskellige religiøse grupper, og at forsoningen derfor er attråværdig. Denne opfattelse af forsoningen er tæt knyttet til den kristne forståelse af soning, og det er muligvis årsagen til at næsten alle forfattere i antologien tager udgangspunkt i den kristne tro. På den ene side kan dette opfattes som positivt, idet de fleste danskere - og dermed læsere - deler dette udgangspunkt, og dermed umiddelbart kan identificere sig med den anvendte forståelsesramme. På en anden side kan man spørge, om det, som de fleste i hvert fald i et vist 
omfang vil betegne som et multi-religiøst samfund, er rimeligt at prioritere en enkelt religion og kun inddrage andre religioner (Buddhisme og Islam) i to enkelte antologibidrag? I forhold til de øjensynlige problemer, som danskere og europæere i bred forstand står overfor, burde den muslimske forståelse af konflikt og forsoning efter min vurdering være tildelt mere plads end Uzma Rehmans bidrag på 11 sider. Til trods for, at der er en stærk bias i forhold til den kristne forsoningstanke, så findes der to kritiske bidrag, som skaber en behagelig distance til det læste. Thomas Brudholm ved at reflektere over om mennesker nødvendigvis har et behov for forsoning, og om det $\mathrm{i}$ virkeligheden ikke bør opfattes som formynderisk at konfliktmægle. Amalie Nørgaard Rathje skaber distance til den kristne soningstanke ved at fremhæve filosoffen René Girards fortolkningen af kristendommen som en kritik af tanken om, at Jesus opofrede sig for at sone menneskets skyld. Kritikken er velplaceret for som det ses af Hans Gammeltoft-Hansens bidrag, så kan Jesus sonoffer i sin ekstrem tolkes som en generel ansvarsfralæggelse for den enkelte. De fleste af forfatterne i Vendepunkter forstår vendepunktet mellem konflikt og forsoning som noget magisk - med en mere litterær betegnelse - et "magisk øjeblik". Definitionen af dette begreb forbliver dog diffus. Det er kærkomment, at Jesper Stange i sit bidrag søger at indplacere begrebet i en bredere sammenhæng. Med udgangspunkt i filosoffen Hans Finks samfundstypologi plæderer Jesper Stange for, at det "magiske øjeblik" bør anskues som en autoritetstype i det moderne samfund, som i Finks terminologi betegnes som forhandlingssamfundet. Forståelsen af det "magiske øjeblik" som en autoritetstype savner dog en nærmere diskussion af begrebet autoritet, og der savnes ligeledes en kritisk refleksion over hvor dækkende begrebet "magisk øjeblik" er for konfliktløsning i historisk perspektiv. Begrebet er relativt nyt, men det behøver ikke udelukke, at begrebet kunne have haft betydning i feudalsamfundet eller i det "moderne samfund".

Sammenlignet med Gudstro i Danmark, som primært har deskriptive og eksplorative formål, udmærker begge de to senere antologier sig ved at have et problemfelt. Problemfelterne giver tilsammen en længe savnet akademisk refleksion over den nyeste udvikling i (verdens-) samfundet. En kritisk indvending i forhold til de tre antologier er, at spørgsmålet om ateisme indtil videre har været begrænset til Morten Warminds bidrag i Gudstro i Danmark. I de tre antologier er en altovervejende fokusering på, hvordan det selvrefleksive individ vælger at udøve mere eller mindre veletablerede former for religion. Modsvaret til selvrefleksive valg er imidlertid fravalg. Et relevant spørgsmål er, om ikke mange som en reaktion på Muhammed-krisen og den seneste tørklædedebat i foråret 2007, har vendt sig bort fra de religiøse forestillinger, og om en sådan bevægelse ikke burde gøres til genstand for opmærksomhed? Særligt interessant kunne det være at undersøge dette med tidsseriedata på tværs af trossamfund. Den problemstilling, som Ole Wævers bidrag fra 2006 tangerer, spørgsmålet om forholdet mellem samfundsret, moral og respekt for 
individuel tro, kunne også underkastes en nærmere analyse. En sådan analyse ville kunne belyse berettigelsen af henholdsvis opdragende foranstaltninger eller sanktioner over for personer, der bevæger sig i ytringsfrihedens gråzone. Yderligere kunne den diskursive sammenkædning af begreberne demokrati, sekularisme, ytringsfrihed og nationalstat, som fremtrædende politikere i disse år artikulerer, også med fordel gøres til genstand for kritisk analyse. Særligt efter Muhammed-krisen fremstår det som påtrængende at forstå, hvordan og hvorfor demokrati og sekularisme konstrueres som en modsætning til islam og fundamentalisme. Endelig kunne forholdet mellem Islam og kristendommen også belyses ud fra den udbredte "gudstro med forbehold" over for såvel den immante som den transcendentale gudsforståelse, som Morten Højsgaard Thomsen indkredser i Gudstro i Danmark. En forståelse af, hvordan den individuelle tro påvirker mulighederne for multireligiøs sameksistens, ville være et gunstigt bidrag i den til tider ophedede politiske debat.

Signe Kjær Jørgensen

E-mail: mail@signekj.dk

\section{Litteratur}

Christoffersen, Lisbeth (red.) 2006: Gudebilleder - Ytringsfrihed og religion i en globaliseret verden. København: Tiderne Skifter.

Raun Iversen, Hans \& Højsgaard Thomsen, Morten (red.) 2005: Gudstro i Danmark. København: Forlaget Anis.

Sjørup, Lene (red.) 2007: Vendepunkter - Religion mellem konflikt og forsoning. Odense: Odense Universitetsforlag.

Steensgaard, Pernille 2003: "Præsten tror ikke på Gud". Weekendavisen 23. maj 2003. 